\title{
COMPARATIVE ANALYSIS ON THE RESULT FOR ARTHROSCOPIC ROTATOR CUFF SUTURE BETWEEN SMOKING AND NON-SMOKING PATIENTS
}

Alexandre Almeida', Márcio Rangel Valin², Rodrigo Zampieri ${ }^{3}$, Nayvaldo Couto de Almeida $^{2}$, Gilberto Roveda $^{2}$, Ana Paula Agostini $^{4}$

\section{ABSTRACT}

Objective: To comparatively analyze the results from arthroscopic rotator cuff suture between smoking and nonsmoking patients. Methods: A group of 286 patients who underwent arthroscopic suturing of primary rotator cuff injuries between June 12, 2002, and May 14, 2008, was analyzed. The patients included in the study were evaluated using the UCLA scale, with a minimum follow-up of 12 months and average of 56.52 months. The variables studied were age, sex, side operated, dominance, profile of cigarette use and UCLA index. Results: This study evaluated a total of 205 patients. Mean age $(p=0.289)$ and sex $(p=0.124)$ were analyzed statistically between the smoking and non-smoking patients and the two groups were considered to be similar. The average UCLA score for the non-smoking patients (143) was 34 (32 to 35). The average UCLA score for the smoking patients (51) was 33 (29 to 35). There was no statistically significant difference in UCLA score $(p=0.123)$ between the smoking and non-smoking patients. For the purposes of statistical analysis, we grouped the small and medium tears (107) and compared these with the large and extensive tears (80), between smokers and non-smokers. There was no statistically significant difference using the MannWhitney test regarding the small and medium tears $(\mathrm{p}=$ 818). There was a statistically significant difference using the Mann-Whitney test regarding the large and extended tears, between the smoking and non-smoking patients, such that the non-smokers showed better UCLA scores $(p=0.038)$. Conclusion: The results from arthroscopic suturing of large and extensive rotator cuff injuries are inferior among smoking patients.

Keywords - Shoulder/surgery; Arthroscopy; Rotator Cuff; Smoking

\section{INTRODUCTION}

The postoperative outcome of arthroscopic rotator cuff (RC) repair is influenced by several technical factors, such as the quality of the tissue being sutured, the surgical technique used, the patient's adherence to the rehabilitation program, age over 65 years, and the patient's expectation of the postoperative outcome $e^{(1-3)}$.

Besides the factors mentioned, some comorbidities, such as smoking, seem to negatively influence the outcome of shoulder surgeries ${ }^{(4-6)}$. A higher incidence of RC tears is (are) observed, as well as the possibility of late diagnosis in smoking patients ${ }^{(7-9)}$, but the literature is controversial as to the extent to which smoking influences the postoperative outcome of $\mathrm{RC}$ repair ${ }^{(10)}$.

Smoking causes vasoconstriction, reducing peripheral oxygen tension, which in turn, inhibits cell proliferation during healing ${ }^{(11,12)}$. This anti-physio-

\footnotetext{
1 - Orthopedic Doctor of the Hospital Saúde and Hospital Pompeia, Caxias do Sul, RS, Brazil.

2 - Orthopedic Doctor of the Hospital Saúde, Caxias do Sul, RS, Brazil.

3 - Resident doctor of the 2nd year of Orthopedics and Traumatology at the Hospital Pompeia, Caxias do Sul, RS, Brazil.

4 - Master's degree in Pediatrics from the Pontifícia Universidade Católica do RS, Brazil.
}

Work carried out at the Hospital Saúde de Caxias do Sul - RS and Residency Service in Orthopedics at the Hospital Pompeia de Caxias do Sul - RS.

Correspondence: Rua Vitório Buzelatto, 222/601 - Madureira - Caxias do Sul, RS - 95020-290. E-mail: bone@visao.com.br

Work received for publication: March 15, 2010; accepted for publication: June 1, 2010. 
logical effect causes a delay of fracture consolidation $^{(13-16)}$, increases the incidence of pseudarthrosis in the humerus ${ }^{(17)}$ and is reported in the literature as being associated with deep vein thrombosis following shoulder arthroscopy ${ }^{(18)}$.

The objective of this trial is to analyze the surgical outcome of arthroscopic RC repair, comparing patients who are smokers and non-smokers.

\section{PATIENTS AND METHODS}

The study used a cross-sectional design.

From June 12, 2002 to May 14, 2008, a group of 286 patients underwent shoulder arthroscopy for rotator cuff repair.

The patients with primary suture of full rotator cuff tears, with follow-up of at least 12 months, and who had no history of upper limb surgery, were selected to take part in the study.

The average age of the 205 study patients was $56.5 \pm 11.2$ years.

In relation to gender, $143(69.8 \%)$ patients were female and 62 were male.

The right side was affected in 159 patients $(77.6 \%)$ and the left in 46 patients. The dominant side was affected in $167(81.5 \%)$ patients.

The RC tears were classified by Cofield as small when they were less than $1 \mathrm{~cm}$; medium when they were 1 to $3 \mathrm{~cm}$; large when they were 3 to $5 \mathrm{~cm}$; and massive, when they were larger than $5 \mathrm{~cm}^{(19)}$. We found 37 small tears $(18 \%)$, 75 medium tears $(36.6 \%)$, 73 large tears $(35.6 \%)$, and 20 massive tears $(9.8 \%)$.

In relation to smoking, $51(24.5 \%)$ of the patients were smokers, 11 were former smokers and 143 were non-smokers at the time of the surgery.

After anesthesia, the patients were positioned in lateral decubitus and the arthroscopic procedure was performed with a $4 \mathrm{~mm}, 30^{\circ}$ degree optical scope. The procedure was always performed by the same surgeon.

After the procedure, the patients, while still under anesthetic in the surgery room, were immobilized with a simple splint for small and medium-sized tears. Patients with large and massive tears were immobilized with a splint with an abduction cushion.

Study patients were assessed using the University of California, Los Angeles (UCLA) shoulder rating scale ${ }^{(20)}$ with an average follow-up period of 56.52 months.
The variables studied were age, gender, smoking habit and UCLA scale rate.

The data were analyzed with the SPSS (Statistical Package for Social Sciences) version 12.0 (SPSS Inc. 1989-2003). For statistical analysis, the following were used: calculation of means, standard deviation, median, frequency and percentage. We used the MannWhitney test to evaluate age, gender and the UCLA rate for different sizes of tears. Fisher's exact test was used to evaluate side and dominance. Differences with $\mathrm{p} \leq 0.05$ were considered significant for a confidence interval of $95 \%$.

\section{RESULTS}

The study evaluated a total of 194 patients.

The average age $(p=0.289)$ and gender $(p=0.124)$ for the smoking and non-smoking patient groups were statistically analyzed, and were found to be similar.

In the analysis of non-smoking patients (143), we obtained an average UCLA rate of 34 (32-35).

In the analysis of smoking patients (51), we obtained an average UCLA rate of 33 (29-35).

No statistically significant difference was observed when the UCLA rate for the non-smoking patients was compared to the UCLA rate for the smoking patients $(\mathrm{p}=0.123)$.

For the purposes of statistical analysis, we grouped small and medium tears (107) and compared them with large and massive tears (80) between smoking and non-smoking patients.

No statistically significant difference was observed by the Mann-Whitney test when the UCLA rate for small and medium tears $(\mathrm{p}=818)$ was compared.

A statistically significant difference was observed by the Mann-Whitney test when the UCLA rate for large and massive tears was compared between the non-smoking and smoking patients, with the non-smoking patients presenting a higher UCLA rate $(\mathrm{p}=0.038)$.

\section{DISCUSSION}

The incidence of the rotator cuff disease in the general population is unknown. It is known, however, that it increases with age, and that by the age of 60 , it is close to $60 \%{ }^{(21,22)}$.

Several scientific studies demonstrate that the patient's age and the size of the RC tear are factors that 
affect the healing of sutured tendons, and worsen the prognosis. Prasad et $\mathrm{al}^{(3)}$ retrospectively evaluated the postoperative of open RC sutures and found the lowest scores, evaluated by the Constant shoulder score, for massive tears and in elderly patients. Boileau et $\mathrm{al}^{(1)}$ determined that age over 65 years and delamination of the supraspinatus and/or infraspinatus tendon are determining factors for a lower healing rate of the tear. Favard et $\mathrm{al}^{(6)}$ draw attention to the imprecise healing of sutured rotator cuffs, and suggest the profile of a good candidate for RC suture repair: patient aged under 65 years, with recent tears, acromiohumeral distance greater than $6 \mathrm{~mm}$, fatty degeneration lower than 2 according to the Goutalier classification $^{(23)}$, and non-smoker. In our study, the average age of the sample is below 65 years, which does not affect the comparative analysis for smoking habits. Similarly, a homogeneous distribution of the $\mathrm{RC}$ tears according to the Cofield classification between smokers and non-smokers does not affect the analysis of the results.

Other factors are still controversial in the literature. Boissonnault et $\mathrm{al}^{(10)}$ analyzed the impact of some clinical comorbidities, including smoking, and were not able to demonstrate, in any significant way, that a higher number of comorbidities worsens the postrehabilitation score in patients who were submitted to $\mathrm{RC}$ repair. Tashjian et $\mathrm{al}^{(5)}$ found significant results to suggest that the association of two comorbidities in the same patient has a negative impact on the postoperative function of the RC suture.

Smoking, once seen as a lifestyle, is now recognized as a form of drug abuse that exposes individuals to countless toxic substances. Its prevalence has decreased following various anti-smoking campaigns, as shown by a survey conducted in 16 Brazilian capital cities in 2002-2003 (12.9\%-25.2\% of the population) compared to the National Health and Nutrition Survey, conducted by IBGE (Brazilian Institute of Geography and Statistics) in 1989, when the prevalence of smoking in the country as a whole was $31.7 \%{ }^{(24)}$.

Smoking seems to be one of the comorbidities that have negative effects on the different phases of treatment of shoulder pathologies. Baumgarten et $\mathrm{al}^{(8)}$ observed a strong association between smoking and $\mathrm{RC}$ disease. The authors found that this association is dose-dependent and smoking-time-dependent. Kane et $\mathrm{al}^{(7)}$ hypothesize that microvascular alterations in the insertion of the supraspinatus and infraspinatus tendon of smoking patients increase the prevalence of tendon tear of the RC. In a study involving 36 human cadavers (72 shoulders), the authors found a higher prevalence of macroscopic and microscopic tears. In the presence of an arthroscopic surgical procedure, the hypotensive anesthesia required for the procedure incurs greater risks when performed in smoking patients ${ }^{(25)}$. The vasoconstriction caused by nicotine may affect the postoperative healing process ${ }^{(11)}$.

Galatz et $\mathrm{al}^{(4)}$ conducted an experimental study in 72 rats (144 shoulders) in which the supraspinatus tendon was severed and repaired to the humeral head. Each group received a subcutaneous implant of nicotine or saline solution. Delayed healing of the supraspinatus tendon and a slower response of the mechanical properties of the tissue after healing were observed in the animal models receiving nicotine. The clinical relevance of this study suggests that smoking is a prognostic factor for the reopening of sutured tendon tears.

Mallon et $\mathrm{al}^{(26)}$, in a retrospective trial, analyzed patients submitted to open RC repairs. They found significantly better results, according to the UCLA scale, for non-smoking patients than for smoking patients. Mallon, however, did not analyze the tears separately by their size or type. In our study, we analyzed only full tears of the RC and we found no statistical significance for the poorest results in the group of smoking patients, in the analysis of the total tears in the sample $(p=0.123)$. Unlike Mallon et $\mathrm{al}^{(26)}$, when we grouped the tears by size, we found statistically significant evidence that the smoking patients with large or massive tears of the RC showed worse postoperative outcomes of the arthroscopic suture $(\mathrm{p}=0.038)$.

Verma et $\mathrm{al}^{(27)}$, seeking to identify the prognostic factors for patients submitted to revision surgery for $\mathrm{RC}$ tears, found statistically significant evidence that non-smoking patients had higher rates for the return to the preoperative functional level. In our study, patients who had undergone revision surgery for the $\mathrm{RC}$ tear were excluded.

The proportion of smoking and non-smoking patients in our study is consistent with the prevalence of smoking in the general population. We paid due attention to the analysis of average age $(p=0.289)$ 
and the proportion of male and female patients in each group $(p=0.124)$ and we observed that the groups had similar characteristics. Neverthless, the difference in numbers of smokers (51) and nonsmokers (143) in the sample can be considered a bias in the study.

\section{CONCLUSION}

The outcome of arthroscopic suture of large and massive rotator cuff tears is lower among smoking patients.

\section{REFERENCES}

1. Boileau P, Brassart N, Watkinson DJ, Carles M, Hatzidakis AM, Krishnan SG. Arthroscopic repair of full-thickness tears of the supraspinatus: does the tendon really heal? J Bone Joint Surg Am. 2005;87(6):1229-40.

2. Henn RF 3rd, Kang L, Tashjian RZ, Green A. Patients' preoperative expectations predict the outcome of rotator cuff repair. J Bone Joint Surg Am. 2007;89(9):1913-9.

3. Prasad N, Odumala A, Elias F, Jenkins T. Outcome of open rotator cuff repair An analysis of risk factors. Acta Orthop Belg. 2005;71(6):662-6.

4. Galatz LM, Silva MJ, Rothermich SY, Zaegel MA, Havlioglu N, Thomopoulos S. Nicotine delays tendon-to-bone healing in a rat shoulder model. J Bone Joint Surg Am. 2006;88(9):2027-34

5. Tashjian RZ, Henn RF, Kang L, Green A. The effect of comorbidity on selfassessed function in patients with a chronic rotator cuff tear. J Bone Joint Surg Am. 2004;86(2):355-62.

6. Favard L, Bacle G, Berhouet J. Rotator cuff repair. Joint Bone Spine. 2007;74(6):551-7.

7. Kane SM, Dave A, Haque A, Langston K. The incidence of rotator cuff disease in smoking and non-smoking patients: a cadaveric study. Orthopedics. 2006;29(4):363-6.

8. Baumgarten KM, Gerlach D, Galatz LM, Teefey SA, Middleton WD, Ditsios K, et al. Cigarette smoking increases the risk for rotator cuff tears. Clin Orthop Relat Res. 2010;468(6):1534-41.

9. Razmjou H, Davis AM, Jaglal SB, Holtby R, Richards RR. Cross-sectional analysis of baseline differences of candidates for rotator cuff surgery: a sex and gender perspective. BMC Musculoskelet Disord. 2009;10:26.

10. Boissonnault WG, Badke MB, Wooden MJ, Ekedahl S, Fly K. Patient outcome following rehabilitation for rotator cuff repair surgery: the impact of selected medical comorbidities. J Orthop Sports Phys Ther. 2007;37(6):312-9.

11. Fang MA, Frost PJ, lida-Klein A, Hahn TJ. Effects of nicotine on cellular function in UMR 106-01 osteoblast-like cells. Bone. 1991;12(4):283-6.

12. Lind J, Kramhoft M, Bodtker S. The influence of smoking on complications after primary amputations of the lower extremity. Clin Orthop Relat Res. 1991;(267):211-7.

13. Schmitz MA, Finnegan M, Natarajan R, Champine J. Effect of smoking on tibial shaft fracture healing. Clin Orthop Relat Res. 1999;(365):184-200.
14. Heppenstall RB, Goodwin CW, Brighton CT. Fracture healing in the presence of chronic hypoxia. J Bone Joint Surg Am. 1976;58(8):1153-6.

15. Labronici PJ, Franco JS, Loures FB, Pinto RA, Hoffmann R. Fatores que afetam a consolidação óssea após tratamento com haste intramedular bloqueada e placa em ponte nas fraturas diafisárias da tíbia. Rev Bras Ortop. 2007;42(5)139-45.

16. Saldanha JB, Pimentel SP, Casati MZ, Sallum AW, Sallum EA, Nociti FH. Histologic evaluation of the effect of nicotine administration on bone regeneration. A study in dogs. Braz Oral Res. 2004;18(4):345-9.

17. King AR, Moran SL, Steinmann SP. Humeral nonunion. Hand Clin. 2007;23(4):449-56

18. Hariri A, Nourissat G, Dumontier C, Doursounian L. Pulmonary embolism following thrombosis of the brachial vein after shoulder arthroscopy. A case report. Orthop Traumatol Surg Res. 2009;95(5):377-9.

19. Cofield RH. Tears of rotator cuff. Instr Course Lect. 1981;30:258-73.

20. Ellman H, Hanker G, Bayer M. Repair of the rotator cuff. End-result study of factors influencing reconstruction. J Bone Joint Surg Am. 1986;68(8):1136- 44.

21. Cofield RH. Current concepts review: rotator cuff desease of the shoulder. $J$ Bone Joint Surg. 1985;67:974-9.

22. Sher JS, Uribe JW, Posada A, Murphy BJ, Zlatkin MB. Abnormal findings on magnetic resonance images of asymptomatic shoulders. J Bone Joint Surg Am. 1995;77(1):10-15.

23. Goutalier D. Pathologie de la coiffe des rotateurs. In: Encyclopédic Médico Chirurgicale. Paris: Elsevier; 1997. p. 350,

24. Instituto Nacional do Câncer. Prevalência de tabagismo no Brasil. Dados dos inquéritos epidemiológicos em capitais brasileiras, 2004 [monografia na Internet]. Rio de Janeiro-RJ: Inca. Available at: bvsms.saude.gov.br/bvs/publicacoes/ tabaco_inquerito_nacional_070504.pdf

25. Is there an optimal timing for smoking cessation? In: Fleisher LA. Evidencebased practice of anesthesiology. Philadelphia: Saunders; 2004.

26. Mallon WJ, Misamore G, Snead DS, Denton P. The impact of preoperative smoking habits on the results of rotator cuff repair. J Shoulder Elbow Surg. 2004;13(2):129-32.

27. Verma NN, Piasecki D, Bhatia S, Romeo AA, Baker AL 3rd, Cole BJ, et al. Outcomes following arthroscopic revision rotator cuff repair (SS-05) Arthroscopy. 2009;25(6):e3. 